\title{
Phytoprotection
}

\section{Research Challenges and Needs for Safe Use of Microbial Organisms : Introduction}

Jean-Charles Côté et Mark S. Goettel

Volume 79, numéro 4, 1998

OECD Workshop - Sustainable Pest Management, Safe Utilization of New Organisms in Biological Control. Montréal, Québec, Canada. September 27-30, 1998.

Atelier de l'OCDE - Gestion durable des ennemis des cultures, Utilisation sécuritaire de nouveaux organismes de lutte biologique. Montréal, Québec, Canada. 27-30 Septembre 1998.

URI : https://id.erudit.org/iderudit/706155ar

DOI : https://doi.org/10.7202/706155ar

Aller au sommaire du numéro

Éditeur(s)

Société de protection des plantes du Québec (SPPQ)l

ISSN

0031-9511 (imprimé)

1710-1603 (numérique)

Découvrir la revue

Citer cet article

Côté, J.-C. \& Goettel, M. S. (1998). Research Challenges and Needs for Safe Use of Microbial Organisms : Introduction. Phytoprotection, 79(4), 41-43.

https://doi.org/10.7202/706155ar d'utilisation que vous pouvez consulter en ligne. 


\title{
Research Challenges and Needs for Safe Use of Microbial Organisms: Introduction
}

\author{
Jean-Charles Côté ${ }^{1}$ and Mark S. Goettel ${ }^{2}$ \\ 1 Agriculture et agro-alimentaire Canada, \\ Station de recherche, St-Jean-sur-Richelieu, (Québec) Canada \\ 2 Lethbridge Research Centre, Agriculture \& Agri-Food Canada, \\ Lethbridge, Alberta, Canada
}

Concerns over the deleterious effects of chemical insecticides has provided a strong impetus for the development of alternatives for use in integrated pest management (IPM). Pathogens are particularly well suited to play an important role in this quest and research into their development as microbial control agents has resulted in the registration and success of many commercial products. Many of the pathogens can be mass produced in vitro and applied using the same methods as for chemicals. There have also been successful products based on pathogens produced in vivo. Improvements in formulation, mass production and storage has resulted in the development of many new novel products within the last few years. There are presently over 20 companies producing microbial control products based on bacteria (22), fungi (19), nematodes (19), viruses (7) and protozoa (1) (Shah \& Goettel, 1999).

Pathogens occur naturally and are often an important factor in the natural regulation of pest populations. Insect pathogens include bacteria, fungi, protozoa, viruses and rickettsia. Methods for their use in Integrated Pest Management (IPM) include conservation, inoculative augmentation, introduction, inundative augmentation and development of refractory hosts by incorporation of a pathogen's genetic material. Conservation entails adoption of practices that conserve naturally occurring pathogens and optimize the conditions required for their desired effect. Inoc- ulative augmentation attempts to induce epizootics in a pest population earlier than would otherwise occur, by introducing the pathogen early in the pest cycle. This technique relies on the consequent natural spread of the disease. Introduction is use of pathogens in "classical biocontrol" whereby an exotic pathogen is introduced and allowed to act and spread "naturally" to control either an indigenous or exotic pest. Inundative augmentation is the release of adequate levels of inoculum that would act to suppress the pest population. It is essentially the "insecticide" approach and does not rely on suppression by the pathogen's progeny. Incorporation of genetic material from a pathogen into a host which then makes it toxic or refractory to the pest is the most recent addition to the methods available. However, since transgenic organisms are the subject of another session within this Workshop, they will not be discussed here further.

Despite many successes, the role of pathogens in pest control as a whole remains minimal. There are many reasons for this. Firstly, most of the methods for use of pathogens best suit the IPM strategy. Unfortunately, despite much publicity and overall support in principle by almost everyone, IPM has by and large failed to materialize as the strategy to manage our pests. It is complex and most producers prefer simpler solutions which basically translates to the insecticidal approach (Winston, 1997). Practices such as 
conservation and inoculative augmentation are seldom attempted. Even if IPM were to take a stronghold, in most cases, a much better understanding of pathogen epidemiology would be required before these methods could be successfully implemented and adopted. Consequently, both conservation and inoculative augmentation will require much research before they can even be contemplated for use in IPM.

The use of pathogens as classical control agents has great potential, but has seldom been utilized. Most successes result from "accidental" introductions of the pathogens themselves. For instance, the origins of the entomopathogenic fungus Entomophthora maimaiga, responsible for the recent epizootics in North American populations of the gypsy moth (Lymantria dispar), an introduced pest, remain a mystery (Hajek et al, 1995). Nevertheless, the spectacular decimation of populations of this ravenous pest that has plagued North American deciduous forests for decades serves as a perfect example of the potential of pathogens as agents for use in classical biological control.

Recent planned introductions of an entomopathogenic fungus (Entomophthora praxibuli) to the United States for control of grasshoppers, an indigenous complex of pests, have received much criticism (Lockwood et al. 1993). Such criticism has seriously jeopardized further use of exotic pathogens as control agents of endemic pests in the United States, even though most are claimed to be very hypothetical and sometimes even far fetched (Carruthers \& Onsager, 1993). Certainly more research on virulence, pathogenicity, host range and epizootiology will be necessary before we are able to adequately address risks and regulatory mechanisms that address them.

Only inundative augmentation of microbials that best fit the chemical paradigm has gained a stronghold, albeit at a relatively small scale. And in many cases, to many people the simple replacement of a chemical by a microbial pesticide has come to mean IPM (Goettel, 1992). Even though microbial pesticides account for only a fraction of the multi-billion dollar pesticide market, use of microbials merely as replacements of chemical insecticides has resulted in the same fate for some microbials, particularly with respect to resistance (Tabashnick 1994). Long-term sustainable use of pathogens inundatively will ultimately require their incorporation into true IPM programs (Lacey \& Goettel 1995).

Secondly, many pathogens are very host specific. There are numerous pathogens that would be very efficaceous, however, the cost of their development and registration far outweigh the potential return. In other words, their most important attribute, as far as their safety and environmental sustainabilty is concerned, is their downfall as far as commercialization is concerned. Even as newer microbial products hit the market, they are being displaced by newer, "softer" chemicals. Consequently the third reason that microbials have not gained a better foothold is that they can seldom compete with chemicals (and more recently, transgenic plants) in the present chemical paradigm.

For the most part, the government's role in pest control has been generally restricted to research and to regulatory oversight. Unfortunately the regulatory oversight has been generally tailored to operate under the chemical paradigm. Consequently, until recently, very little has been done to promote alternatives and true IPM. For the most part, IPM has been left as the responsibility of extension type agencies. Some progress has been made and governments are starting to move in the right direction. For instance, the formation of the National Biological Control Institute (NBCl) at the USDA's chief regulatory agency, the Animal and Plant Health Inspection Agency (APHIS) and the Alternative's Office at Canada's Pest Management Regulatory Agency are signs that we are finally moving, ever so slowly, towards IPM. However, if IPM is ever to become a reality, with a significant role played by pathogens, then government, producers and consumers will have to take on a much more pro-active role. 
The fourth reason that microbial control has had difficulty in establishing itself is related to "safety." Because microbial control agents fall under many of the acts passed to ensure safety of chemical pesticides, and because the public has a general fear of protists, microbials have been subjected to regulatory oversight. Of the five methods outlined above, only one, conservation, is essentially free of regulatory oversight. Unfortunately, initially, regulatory requirements were cumbersome and in many cases ludicrous, as regulatory agencies attempted to regulate microbials using essentially the same protocols and requirements designed to regulate chemicals. After a 10 to 20 year hiatus, regulations in many countries have started to become more reasonable and address the pertinent concerns. However, many regulatory requirements require meaningless testing which provide meaningless information as far as safety is concerned, while at the same time, many pertinent safety questions remain unanswered. There is certainly need for improvement, much of which will depend on new research tailored to answer specific safety issues. Most of today's speakers will attempt to tackle these specific issues.

\section{REFERENCES}

Carruthers, R.I. and J.A. Onsager. 1993. Perspective on the use of exotic natural enemies for biological control of pest grasshoppers (Orthoptera: Acrididae). Environ. Entomol. 22: 885-903.

Goettel, M.S. 1992. Whatever happened to the "I" in "IPM"? Editorial, Society for Invertebrate Pathology Newsletter 24 (2): 5-6.

Hajek, A.E., R.A. Humber \& J. S. Elkinton. 1995. Mysterious origin of Entomophaga maimaiga in North America. Am. Entomol. 41 (1): 31 - 42

Lacey, L.A. \& M.S. Goettel. 1995. Current developments in microbial control of insect pests and prospects for the early $21^{\text {st }}$ century. Entomophaga 40: 3-27.

Lockwood, J.A. 1993. Environmental issues involved in biological control of rangeland grasshoppers (Orthoptera: Acrididae) with exotic agents. Environ. Entomol. 22: 503-518.

Shah, P.A. \& M.S. Goettel. 1999. Directory of Microbial Control Products \& Services. Microbial Control Division, Society for Invertebrate Pathology (in preparation).

Winston, M.L. 1997. Nature Wars: people vs. pests. Harvard Univ. Press, Cambridge, Mass. $210 \mathrm{pp}$. 